\title{
Emergent Literacy Based on Wordless Picture Book to Introduce Minangkabau Cultural Value and Identity for Early Childhood
}

\author{
Delfi Eliza \\ Pendidikan Anak Usia Dini, Universitas Negeri Padang, \\ Padang, Indonesia \\ deliza.zarni@gmail.com
}

\begin{abstract}
Emergent literacy by promoting wordless picture book is a great way for developing the literacy skill of children. The storybook using a good illustration of Minangkabau character is still not widely used in kindergarten to develop emergent literacy of the children. Through the book material that proposed wordless picture book based, the children word recognition skill, the ability to think, concepts thinking skill, and language skill of the children can increase. The strategy used to enhance emergent literacy by developing models that can be applied to motivate and awaken the awareness of reading habits can be begun from an early age. This article explains the importance of introducing Minangkabau values and identity by using wordless picture book for early childhood. Furthermore, introducing traditional wordless picture book based on folklore to develop children's literacy ability needs to be done.
\end{abstract}

Keywords-emergent literacy; wordless picture book; Minangkabau cultural value and identity

\section{INTRODUCTION}

The idea that some language skills can be developed through interaction is well known in decades. Children who expose to their language inputs will be able to form the language to respond adults' feedback in producing language. Parents who always speak directly to their children with a long time can be predicted to give a significant role for vocabulary understanding and words producing. Kammed has done studies at school that described the influence of teachers' language input. It is also found that the lexical differences of teachers' vocabulary can be predicted due to emergent, word recognition, the ability to understand vocabulary and emergent writing. The quality of teachers' language and good interaction in the classroom are important matters in language development [1].

Some early researches, started since 1960 , have made us aware of the children competence and literacy skills. [2] have revealed that most children read faster before they enter formal school without formal instruction. Investigations also reveal about how the environment supports the development of literacy. Three-year-olds are able to read common words in their environment such as Burger King, McDonald's, Exxon, and Sugar Pops [3]. The results of this investigation show that very young children understand images, letters, and words, and that their ability to recognize familiar print symbols is the beginning of the reading process. According to Goodman (1984), "literacy roots" began in childhood by most children in literate societies[3].

Moreover, the research indicates that reading provides benefits to children for the acquisition of their reading ability. Reading enhances literacy skills, improves interest in books and learns to read, improves information and meaning from story structure, and makes students familiar with written language books compared to spoken language [4]. Well-crafted stories have settings (introduction of time, place, and character), themes (main role or core issues), plots (instances where the main actor tries to solve problems and achieves goals), and solves problems (solving stories or problem solving and end of story). By listening to many well-crafted stories, children can predict what will happen next in a story they do not know based on their understanding of the structure and elements of reading [5]. The children take benefits in terms of the comprehension skills of their assimilation and habit with vocabulary and sintax structures in the books they have read. Children who have often been given early reading tend to learn to read faster than others and learn to read more easily[6].

Meanwhile, several studies suggest that wordless picture book is not only recommended for children to read, but to engage children actively in class activities and to promote higher level story verbalization. Therefore, there is a wordless picture book, which challenges pre-school children to link writing with literacy skill when the mother of a Latin-speaking teacher uses storytelling as a bridge. Using storytelling books improves educating children elicit information from children.

A study advocates that wordless picture book enhances the social imagination that plays an important role in the rules of reading. Interestingly, this new study shows that 
children with ADHD provide benefits for children effective scaffolding for children involved in the activity.[7]

However, in the setting of early childhood education, the picture book is used with the aim that in the process of development of children pre-reading skills, such as sequential thinking ability, the ability to distinguish (visual discrimination) and inferential thinking. Sequential thinking is an activity that involves logical thinking, sequencing, real, needing practice, timelines to pay attention to details and organize. Inferential thinking is the reason for making or drawing conclusions based on previous evidence of knowledge. Children can relate the information provided with prior knowledge of experience and belief. In other words, they make estimates or predictions, the child can be involved in asking, collecting and analyzing evidence, making connections between prior knowledge and new information. In addition, the most important is that the picture books are useful to shape the emergent literacy for early childhood. The emergent literacy is in the sense of readiness to read and write through visual illustrations of images contained in a story that is well designed, interesting, and its colors captivate the child to read it.

This study explains the effect of reading books with teachers and discussing after reading of traditional storybook Minangkabau, and explain how its impact to the development of language and literacy children early childhood. The same study has been conducted in the United States which in conclusion states that the quality of learning designed to improve literacy skills is very effective for the language minority (LM) effectiveness of AUD for a significant effect to improve knowledge of writing, mixing letters or composing into words, very effective learning to improve early literacy skills from language minority (LM) [8].

\section{DISCUSSION}

\section{A. Emergent Literacy}

Emergent literacy as the basic writing of children's writing on book pages, although no letters can be seen. Children who know the difference between graffiti and such images certainly have some differences between writing and illustration. Similarly, when a child tells a familiar storybook while looking at the drawings and prints and emphasizes the reading, we recognize the activity as legitimate literary behavior, although it cannot be referred to as reading in the conventional sense.

The emergent literacy development is very sensitive to children because they seek strength rather than weaknesses that children have. The development of literacy approached in this way accepts children at whatever level of literacy they enable and provides lessons for instruction based on individual needs.

Literacy as the result of child involvement in literacymediated literacy activities. Literacy is a social collaborative interaction that follows activities that make this very important for child development. Literacy not only teaches the child a social function but literacy also connects preoccupation and satisfaction so that it can increase the child's desire to engage in literacy activities.[9]

According to Marie Clay the term "emergent literacy skills" is described as a skill in how a child interacts with a storybook and presents it to writing and reading[10]. Nevertheless, the term is defined as the formal introduction in which the child is not formally able to read and write formally but interacting with the text and the picture (The Teachers and Tezby, 1986). Emergent literacy is a process that begins at birth and it grows as a stage where reading and writing are done conventionally. In this study, it was defined also the term literacy interrelation that means as relationships between several aspects of language including speaking, listening, reading and writing. Through share book reading, in which the variations of language such as literacy, teaching model, and various forms of literacy response occurs, delicates the students to literacy skill. The children can listen to an intellectual capability, personal, and performance analysis [11].

The first emergence literacy phrase has attracted the attention of educators interested in early-stage literacy. Emergent literacy that emerges assumes that the child acquires some knowledge of the language, reading, and writing before entering school. The development of literacy begins early in life and is ongoing. There is a dynamic relationship between communication skills; each affecting the other in the development process. Development takes place in the everyday context of home and society. Children of every age have certain literacy ability, although these skills are not fully developed or conventional because we recognize mature reading and writing [12]. Emergent literacy as the basic writing of children's writing on book pages, although no letters can be seen. Children who know the difference between graffiti and such images certainly have some differences between writing and illustration. Similarly, when a child tells a familiar storybook while looking at the drawings and prints and emphasizes the reading, we recognize the activity as legitimate literary behavior, although it cannot be referred to as reading in the conventional sense. This matter leads the children to the readiness to read.

Readiness to read is a result of the maturity and experience that children get from the environment, thus reading readiness can be improved through giving experience to the child, since the child is very young. Readiness to read, is "teachable moment for reading, a point in time when the pupil is ready to learn how to read" months during which time the child gradually changes from reader to begining reader"[13]. Readiness is not a time period in which a child moves from a non-reading behavior to an early reading. Readiness for children is treated as a transitional period.

Readiness provides an advantage in early reading learning, also known as prereading, emergent literacy, early literacy. Some experts argue that a set of ideas about how children learn about reading, writing and understanding written language is based on theory, research and practice [14].. However early literacy as an initial reading readiness time is the basis for growing awareness that writing has a meaning. 
To learn means to read in which child has a feeling of sensitivity to writing.

In four or five aged children, there is an increased understanding of writing when children read stories containing familiar alphabet fonts. Children begin to recognize words in the context of the environment such as common labels and signs -sign. This is a process that helps a child learn how to read and make children recognize the words in that context. Further awareness of writing and supported through books like other forms of writing within the school environment, through charts, labels, bulletin boards around the child's environment contribute to print awareness [15].

From some of the expert opinions above, it is clear that readiness is the initial stage of the child's awareness of the written language and is the basic process of children to read. In this case, there are many views on reading readiness over the years but it all depends on when, with whom and for what is used. In this case the view of readiness is relative to the context of its use.

Readiness is an entry behavior for a person in learning to read, the child's early ability before learning is given and readiness to accept new teaching materials in a learning process. Readiness reading from the cognitive flow, Ausubel states: "One of the most important factors affecting learning is what the learner already knows," so the child can adjust to the learning task. In other words readiness means adjusting the child with the learning task. General goal of early learning is to bridge the gap between child language knowledge and its proximity to writing [16].

Many factors that can affect reading readiness of kindergarten children that can improve reading readiness [17] are:

1. Normal visual and auditory physical condition is a condition for success in reading, without which the child will not be successful in reading. Normal hearing is also very necessary in recognizing the symbols of the mold that includes physical conditions. (1) is the mental age of several studies saying that mental maturity of children is a factor for success in initiating reading.

2. Ability to succeed in reading. (1) is the factor of emotional stability, (2) The ability to remember, it is necessary to know the continuation of the story and also the readiness to recognize new words. 3) Perception relationship. A successful child in reading should be able to relate to what is known to the symbol of the mold. (4) Sensory discrimination. Children should receive knowledge of written symbols through normal hearing, the ability to distinguish correctly with respect to the shape of size, and color with normal vision.

3. Intellectual factors (1) understanding of concepts. (2) the meaning of words. (3) experience. (4) organization and classification of ideas (5) the concept of reading. (6) experience with literature (7) child's attitude to reading.

4. And socioeconomic factors.

Meanwhile, according to Marta Dalman, factors related to reading readiness are: Age and gender, attitudes toward reading, mental maturity, emotional social development, language development, and educational factors.
The repetition of reading the same story is also an important important strategy. Reading for children can provide an understanding of the function of writing, in terms of how the print is used and what people do when they read. Children with experience reading storybooks learn how to deal with books and are sensitive to plot: beginning, middle, and end: and concept of authorship (Clay, 1970a: Torvey \& Kerber, 1986). Mason (1980) adds that the reading function for children not only increases their awareness of the functions, forms and conventions of printed books, but also builds metacognitive capabilities about approaches to reading tasks and how to interact with teachers and parents.

Based on some opinions above it can be concluded that the factors that affect readiness read very much for that educators should pay attention to these factors in various activities in kindergarten. Growth in children not only occurs in the physical aspects but also the mental and emotional aspects. Teachers and people should not demand a child to do a job before he actually reaches the maturity level of intelligence and emotion that allows him to do some work.

However much stimulation their child receives can not learn until their development is ready to do so. It requires a certain physical and mental basis that must exist before a new ability can be built on it. If the child is not ready to learn, then the effort for them to waste time and no use it will lead to behavior that is not cold if the child is ready to learn, then their teaching will work well because the child has shown interest to learn something .

Similarly in reading readiness, to be successful in learning to read, requires a state of preparedness in children that includes various mental and physical maturity of children. None of the knowledge of the reading process is more significant than the development of children's literacy.

Based on the above description it can be concluded that readiness is an important factor in the success of children learning to read. Readiness reading is a state that allows a child to have a reading skill, characterized by a number of specific behaviors this is due to the maturation of his organs and experiences. The behavior can actually be observed as long as we want to pay attention to it with little difficulty. Among others, through a child's curiosity about stories, picture books and so on.

Child readiness criteria are closely related to several factors, so the child is said to be ready to read, if the child has met several criteria according to the factors that influence readiness of children. There are criterias of a child who is ready to read through a few questions [19]: (1) does the child already understand spoken language? This expert can be seen when a child chats, asked or asked to do something, (2) Is the child able to clearly speak the word? This is seen when, the child asks, talks or mentions an object, (3) Does the child remember words, especially object names? (4) Is the child able to pronounce the letters? (5) Is the child able to show interest in reading? This can be seen from children's behavior in the form of holding or opening books, imitating reading and scribbling paper, (6) Is the child able to distinguish well? That 
is the ability of hearing and sight to distinguish objects with sound.

Examples of activities that provide reading readiness experiences for children commonly used to help children in word recognition are described as follows: (1) Name of the child. The easiest word to teach children is his name. He saw his name in the readiness book reading it and in the picture and on the drawings displayed by the teacher. In addition there are several occasions where the teacher will write the child's name on the blackboard for birthday celebrations, special assignments, and the like. The child will notice the similarity between his name and the other name. (2) Color names. To teach the color names in children, by making large color circles, can be placed on the board or table. Color names are printed on a white card. The child selects a card, mentions it, and puts the color name in the appropriate colored circle. (3) Matching words with images. All children in the readiness group are able to identify a large number of objects and images of objects. The familiar images were found, and the word names were printed on separate cards: cars, ducks, cows, houses. Each child selects a word and places it under the appropriate image. (4) Objects in the class. A word card is made for known objects in the class, such as doors, tables, windows, books, chairs. The child selects a word card, shows it to a group friend, and touches the object.

From the above example it can be concluded that the introduction of early reading for the child can be done through activities of some meaningful activities for the child, starting from the closest to the child, through fun activities, using real or concrete objects that can be manipulated by the child.

\section{B. Wordless Picture Book}

Wordless picture books describe almost nonexistent words and illustrations or images that give meaning and narrative function. Unlike the case with textbooks when reading a textbook without a text (wordless picture book) the reader makes the meaning of the illustrations of the picture.

The picture book is the best and positive way in the literacy acquisition in accordance with the quality of the book. The children interaction with storybooks is an effective way for literacy development by integrating literature into the curriculum [20].

Books with wordless picture book can also be used for pedagogic purposes including emergent literacy, second language, learning, creative writing and comprehensive reading.

\section{Minangkabau Cultural Value and Identity}

Adat comes from the Sanskrit language, formed from a "and" dato, a "meaning no and dato" means something material. So custom means everything that is not material. With the existence of adat, society is governed by the system contained in cultural values, laws, and rules in interacting with others. In line with Rasjid's earlier concept, explaining that, cultural issues are already inherent and become the clothing of life as well as self-esteem for a person in Minangkabau. If the Minangkabau people are said to be not cultured will be angry characterized by a red facial expression, because it has become a living garment. This means that custom has been entrenched in the lives of Minangkabau people.

There are two components of adat and Islam complement each other (complimentary). Like the union of water and oil in milk. Other values like "baso, malu" and the other character is a fragment of the mind. Shame is a dynamic in indigenous peoples, "nan sakik kato, nan malu tampak". 'Malu indak buliah diagieh, suku indak buliah dianjak". Malu sorang malu basamo". It is reflected in the following rhyme pantun associated with the mind [21].

$$
\begin{gathered}
\text { talangkang tjarano baso, } \\
\text { badarai carano kendi, } \\
\text { padi nan samo rang gantangkan } \\
\text { baganggang karano baso, } \\
\text { batjarai karano budi, } \\
\text { itu nan samo rang pantangkan }
\end{gathered}
$$

Budi got the main place in the association of live life. Adat as a whole system, a form of value system based on ethics, which represents the ideal behavioral pattern. So in human ahklak (human morality) it must be based on the mind, and the understanding of the mind, human conduct, human acts based on the mind, so that the association of life useful, and good relations between human beings. Thus a foundation that solidifies the Minangkabau people is the harmony of contradictions.

Indeed, in the face of the problem of conflict between individuals and the association of life many of its solutions depend on the morals and the establishment of human beings. The foundation is found in the Minangkabau society called the mind. Budi is a close and subtle bond in the social life.

For instance, the story of Sabai Nan Aluih as one of traditional story in Minangkabau that was popular for Minangkabunese. Sabai's mother is a loving parent educating and raising her children, her father as well but her love is very much to the boys. Boy is left to his heart, not taught life lessons as a man, unlike Sabai he got a lot of life value from his mother as a girl in the realm of Mingkabau. How to glorify guests, attend invitations, courtesy, and defend the family all in the fooled from the mother of Sabai nan aluih. Make children bold, confident and knight. Although she is a girl she can defend the family.

a) First Learning Activities 1) Development of Cognitive ability (Cognitive) Children are expected to understand (understand) with cultural values in Sabai nan aluih story. Those values are benevolent, loving, knight, not spoiled, polite, clever friends etc. With an indicator the child can have awareness about value, understand value, be able to give reasoning, and decision making.

2) The development of feeling (feeling)

Through this story children are stimulated by their feelings as girls can appreciate the good Minangkabau cultural values and do not imitate the 
not good Children will be inspired through this story in order to understand the values that exist in the story and daat express with their own language and giving. With word indicator, empathy, love of kindness and self-control.

3) Behavioral (Applying Behavioral)

Children can apply the good values of the story in their daily activities as well as in school. In addition, children are expected to abandon bad values. Bad value becomes a learning material for children and parents. Children are expected to play characters according to the story. Characterization of the characters can be done through role play activities. With indicators for the application of competencies, desires and habits..

\section{CONCLUSION}

As the result of the discussion that described in this article, it can be concluded that children's literature based on wordless picture book can be used as a tool and media for introducing Minangkabau traditional value and identity. The wordless picture book shared to the children not only stimulate children's critical thinking, cultural identity concept that include "budi, rasa malu, saiyo sakato, gotong royong" etc but also can be a significant windows for their thinking about Minangkabau cultural value and identity.

\section{References}

[1] Leydi Johana Chaparro-Moreno*, Florencia Reali, Carolina MaldonadoCarrẽno. Wordless picture books boost preschoolers' language production during shared reading. 10.1016/j.ecresq.2017.03.001

[2] Morrow, Lesley Mandel. Literacy Development in The Early Development Years. (Second Edition) Boston: Allin and Bacon, 1993

[3] Morrow, Lesley Mandel. Literacy Development in The Early Development Years. (Second Edition) Boston: Allin and Bacon, 1993 P. 122

[4] Morrow, Lesley Mandel. Literacy Development in The Early Development Years. (Second Edition) Boston: Allin and Bacon, 1993 P.116
[5] Morrow, Lesley Mandel. Literacy Development in The Early Development Years. (Second Edition) Boston: Allin and Bacon, 1993 P.125

[6] Eva L,Essa.Introduction to Early Childhood Education. $4^{\text {th }}$ Edition. (Thomson: Delmar Learning, 2003) p.346.

[7] Kathryn E. Bojczyka,*, Anna E. Davisb, Verda Ranab. Mother-child interaction quality in shared book reading: Relation to child vocabulary and readiness to read. 10.1016/j.ecresq.2016.01.006.

[8] J. Marc Goodricha,*,1, Christopher J. Lonigana,*, Jo Ann M. Farver Impacts of a literacy-focused preschool curriculum on the early literacy skills of language-minority children. 10.1016/j.ecresq.2017.02.001

[9] Morrow, Lesley Mandel. Literacy Development in The Early Development Years. (Second Edition) Boston: Allin and Bacon, 1993 P. 123

[10] Morrow, Lesley Mandel. Literacy Development in The Early Development Years. (Second Edition) Boston: Allin and Bacon, 1993

[11] Nahla M. Gahwaji, The Effects Of Two Different Instructional Programmes On Literacy Skills Of Kindergarten Children. Journal of International Education Research - First Quarter 2016

[12] Chaparro-moreno, Leydi Johana Reali, Florencia,Maldonado-carre, Carolina. Early Childhood Research Quarterly Wordless picture books boost preschoolers ' language production during shared reading. 10.1016/j.ecresq.2017.03.001. (P.52-62)

[13] http://www.What are Reading Readiness skills htm.(SIL Internationl 1999).p.1.

[14] Campbell, Linda Bruce Campbell, Dee Dickinson, Theaching and Learning through Multiple Intellegences. (terjemahan Inisiasi) Depok: Inisiasi Press, 2002.

[15] Morrow, Lesley Mandel. Literacy Development in The Early Development Years. (Second Edition) Boston: Allin and Bacon, 1993.P 117

[16] http://www.What are Reading Readiness skills htm.(SIL Internationl 1999).p.1.

[17] Lovitt, Thomas C. Introduction Learning Disabilities. United States of America: Allyn and Bacon, 1989.

[18] Brewer, Jo An. Introduction to Early Childhood Education. Preschool Through Primary Grades. United States: Pearson Education,Inc, 2007.

[19] Tampubolon. Mengembangkan Minat dan Kebiasaan Membaca pada Anak Bandung: Angkasa,1991.

[20] Mary Renck Jalongo,1,4 with Denise Dragich,2 Natalie K. Conrad,3 and Ann Zhang2. Using Wordless Picture Books to Support Emergent Literacy. Early Childhood Education Journal, Vol. 29, No. 3, Spring 2002

[21] Taufik Abdullah in (Goh Beng-Lan, Adat and Islam An Examination of Conflict in Minangkabau, Decentring and Diversifying in South East Asian Studies. Perspective from Region (Singapore: Institute South East Asian Studies, 2011), h. 430. 